\title{
PERSEPSI KAUM GAY TENTANG FENOMENA LGBT (LESBIAN, GAY, BISEKSUAL DAN TRANSGENDER) DI KOTA SEMARANG
}

\author{
Isy Royhanaty ${ }^{1}$, Maria Petrolena ${ }^{2}$ \\ 1,2Prodi Kebidanan STIKES Karya Husada Semarang \\ Email : royhanatyisy@gmail.com
}

\begin{abstract}
ABSTRAK
Latar belakang : Fenomena Lesbian, Gay, Biseksual dan Transgender, atau yang biasa disingkat LGBT merupakan salah satu fenomena yang tak pernah habis-habisnya untuk dibahas sepanjang sejarah manusia. Tujuan : Untuk mengetahui Persepsi Kaum Gay Tentang Fenomena LGBT di Kota Semarang. Metode : Desain penelitian yang digunakan adalah penelitian kualitatif dengan pendekatan fenomenologi. Teknik pengumpulan data dengan wawancara mendalam. Jumlah partisipan 4 orang angota komunitas Gay. Hasil penelitian: Partisipan mengetahui tentang pengertian LGBT namun kurang lengkap. Partisipan terjun ke LGBT secara alami, yaitu ketika masa puber (SMP). Partisipan beranggapan bahwa selama ini masyarakat yang kontra terhadap LGBT lebih banyak dibandingkan masyarakat pro, hal ini disebabkan karena banyaknya pemberitaan-pemberitaan yang negatif tentang LGBT di media, serta kurangnya informasi tentang LGBT yang diperoleh masyarakat. Parsitipan merasa tidak ada diskriminasi di tempat kerja, karena mereka memberitahu tentang jati dirinya kepada pimpinan dan rekan kerja. Partisipan beranggapan bahwa orientasi seksual mereka juga berpengaruh terhadap kesehatan mereka, namun tidak setuju bila seks bebas diidentikan dengan komunitas mereka dan komunitas mereka yang dikatakan menjadi salah satu penyumbang terbesar HIV/ AIDS, karena perilaku seks bebas juga dilakukan oleh kaum heteroseksual dan penyumbang HIV/ AIDS terbesar justru berasal dari kaum heteroseksual. Kesimpulan : Partisipan sudah mengetahui tentang LGBT namun belum lengkap. Partisipan mulai menyadari orientasi seksualnya sejak masa SMP. Partisipan menganggap masyarakat yang pro sudah menerima LGBT namun yang kontra belum menerima diakibatkan oleh kurangnya informasi yang didapat. Partisipan sudah memberitahu jati diri mereka di tempat kerja. Partisipan tidak setuju dengan pernyataan bahwa seks bebas diidentikkan dengan komunitas mereka.
\end{abstract}

Kata Kunci : Lesbian; Gay; Biseksua; Transgender; Pengetahuan

\section{GAY PERCEPTION ABOUT LGBT (LESBIAN, GAY, BISEXSUAL AND TRANSGENDER ) PHENOMENON IN SEMARANG}

\begin{abstract}
Background: The phenomenon of Lesbian, Gay, Bisexual and Transgender, or commonly abbreviated as LGBT is one phenomenon that never inexhaustible to be discussed throughout human history. Objective : To determine the perception of LGBT Gay About phenomenon in the city of Semarang. Methods : The study design used is qualitative research with phenomenological approach. Data collection techniques with in-depth interviews. Number of participants 4 Gay community members. Results : Participants know about the understanding of LGBT yet incomplete. Participants plunge into LGBT naturally, when puberty (SMP). Participants assume that during this time the counter against the LGBT community more than the pro, this is because many news-negative publicity about LGBT in the media, as well as the lack of information about the LGBT community acquired. Parsitipan feel there is no discrimination in the workplace, because they tell about their identity to the leadership and co-workers. Participants believe that their sexual orientation is also an effect on their health, but do not agree that free sex is identified with their community and their community was said to be one of the largest contributors of HIV / AIDS, because of sex behavior is also done by heterosexuals and contributor to HIV / AIDS The actually comes from heterosexuals. Conclusion : Participants already know about LGBT but incomplete. Participants began to realize his sexual orientation since junior high. Participants assume the pro already received the LGBT but the counter has not received due to the lack of information obtained. Participants are informed of their identity in the workplace. Participants did not agree with the statement that free sex is identified with their community.
\end{abstract}

Keywords : Lesbian; Gay; Bisexual; Transgender; Knowledge 


\section{Pendahuluan}

Fenomena Lesbian, Gay, Biseksual dan Transgender, atau yang biasa disingkat LGBT merupakan salah satu fenomena yang tak pernah habis-habisnya untuk dibahas sepanjang sejarah manusia. Akronim LGBT mulai muncul sekitar tahun 1988. Baru pada tahun 1990-an, istilah ini banyak digunakan. Meskipun komunitas LGBT menuai kontrovensi mengenai penerimaan universal atau kelompok anggota yang berbeda (Biseksual dan Transgender kadang-kadang dipinggirkan oleh komunitas LGBT), istilah ini dipandang positif. Akronim ini pun secara umum dianggap mewakili kaum yang tidak disebutkan. Lesbian merupakan istilah yang umum digunakan untuk para perempuan yang mengarahkan pilihan orientasinya kepada sesama perempuan, atau perempuan, yang mencintai perempuan, baik itu secara fisik, seksual, atau emosional. Gay atau Homo adalah istilah untuk laki-laki yang memiliki kecenderungan seksual kepada sesama pria atau pria yang mencintai pria baik secara fisik, seksual, atau emosional. Biseksual adalah istilah untuk seseorang penyuka sejenis atau dua jenis kelamin, yaitu wanita dan pria. Biseksual kerap dipandang sebagai salah satu bentuk penyembunyian identitas homoseksual, atau sebagai transisi antara identitas heteroseksual dan identitas Gay dan Lesbian. Transgender adalah orang yang cara berperilaku atau penampilannya tidak sesuai dengan peran gender pada umumnya (Daryono, 2013).

Sebuah studi pernah mengungkapkan bahwa hubungan pria Gay justru lebih rentan terhadap beberapa penyakit tertentu, khususnya yang berhubungan dengan urusan seksual. Gaya hidup yang mengarah pada seks yang tidak sehat biasanya adalah pemicu penyakit yang menyerang pasangan sesama jenis. Dibandingkan dengan wanita Lesbian, pria Gay malah disebut sebagai orang yang lebih berisiko kesehatannya. Berdasarkan penelitian dari John R. Diggs yang telah dilaporkan dalam jurnal Corporate Resource Council, aktivitas pasangan pria Gay lebih berisiko terhadp masalah kesehatan mereka. Kontak dengan anal memperbesar kesempatan menularkan berbagai penyakit, karena ada lebih banyak bakteri yang bersarang di bagian tersebut. Penyakit yang menyerang pasangan pria Gay bisanya adalah HIV, Sifilis, Hepatitis, dan infeksi Chlamydia (Adnamazida, 2012).

Pada tanggal 26 Juni 2015, Mahkamah Agung Amerika Serikat menetapkan bahwa pernikahan sesama jenis legal di seluruh wilayah Amerika Serikat, menyusul 20 negara lainnya yang sudah terlebih dahulu melegalkannya seperti Belanda dan Kanada. Pelegalan ini menimbulkan banyak kritik dari berbagai pihak, sehingga menimbulkan banyak pro dan kontra. 
Di Indonesia sendiri, pelegalan LGBT ini juga masih menjadi pro dan kontra, banyak pihak yang mengkritik, namun tidak sedikit juga yang mendukung pelegalan LGBT ini, mereka pun dikecam habis-habisan oleh orang-orang yang anti LGBT. Padahal, menurut survei CIA, jumlah populasi LGBT di Indonesia adalah ke-5 terbesar di dunia setelah China, India, Eropa, dan Amerika (Rahman, 2015).

Di Kota Semarang sendiri terdapat 2 komunitas Gay, salah satunya adalah Semarang GAYa Community (SGC). SGC sendiri merupakan sebuah organisasi berbasis komunitas (Gay dan LSL lainnya) yang non-pemerintah dan independen. Dengan mengangkat isu utama berupa HIV dan AIDS sebagai alasan utama berdirinya komunitas ini. Oleh sebab itu, SGC membangun kerjasama dengan berbagai pihak, yakni salah satu lembaga donor GF (Global Found) dan SSR Yayasan Graha Mitra Semarang yang memang memiliki program penanggulangan HIV dan AIDS dalam kelompok Gay dan LSL di 8 wilayah di Jawa Tengah.

Berdasarkan latar belakang diatas, maka peneliti tertarik untuk melakukan penelitian dengan judul "Persepsi Kaum Gay Tentang Fenomena LGBT di Kota Semarang”. Penelitian ini berfokus pada pengetahuan tentang LGBT, alasan kaum gay terjun ke LGBT, pendapat keluarga dan masyarakat yang pro dan kontra, dunia Pekerjaan yang dimasuki oleh kaum gay, serta dampak orientasi seksual yang menyimpang terhadap kesehatan.

\section{Tinjauan Teoritis}

LGBT atau GLBT adalah akronim dari Lesbian, Gay, Biseksual, dan Transgender. Istilah ini digunakan semenjak tahun 1990-an dan menggantikan frasa 'komunitas Gay' karena istilah ini lebih mewakili kelompok-kelompok yang telah disebutkan (Keith, 2007).

Lesbian adalah istilah bagi perempuan yang mengarahkan pilihan orientasi seksualnya kepada sesama perempuan atau disebut juga perempuan yang mencintai perempuan baik secara fisik, seksual, emosional, atau secara spiritual (NLGJA, 2012). Di dalam lesbian terbagi lagi menjadi beberapa bentuk, yaitu Butch dan Femme. Butch digunakan untuk mengidentifikasi seorang perempuan lesbian yang menunjukkan karakter yang distereotypke-kan sebagai maskulin. Sedangkan Femme digunakan untuk mengidentifikasi seorang perempuan lesbian yang menunjukkan karakter yang distereotype-kan sebagai feminin. (Anonim, 2012). Gay atau Homoseksual merupakan sebuah masalah yang kompleks. Homoseksual menurut Frank S. Caprio adalah semacam tingkah laku seksual yang terjadi oleh sebab psikis, bukan oleh sebab fisik. Biseksual adalah orientasi seksual yang berfokus pada ketertarikan fisik dan romantisme kepada kedua jenis seksualitas baik pria maupun wanita. Seseorang yang biseksual akan 
mengalami konflik dengan komunitas homofobia, tetapi konflik yang demikian bukan merupakan gejala dari gangguan pribadi. Yayasan American Psychological (APA) mengidentifikasikan bahwa salah satu yang sangat signifikan bagi kaum Homo dan Biseksual adalah kepuasan mereka terhadap orientasi seksual mereka dan tidak ada gejala kelainan tertentu. Transgender adalah sesuatu yang meliputi banyak orang dengan identitas yang spesifik. Intinya, seseorang yang beridentitas Transgender memiliki gender dengan jenis kelamin yang berbeda secara biologis. Ada perbedaan bentuk Transgender, diantaranya cross-dresser, drag queens, drag kings, wanita yang maskulin, dan laki-laki yang gemulai (NLGJA, 2012). Cross-dresser (dulu disebut Transvestite) adalah seseorang yang memakai pakaian yang dianggap tipikal dengan karakteristik gender yang bukan 'seharusnya' (sesuai harapan masyarakat) dalam waktu-waktu tertentu, akan tetapi tidak mau melakukan operasi pergantian alat kelamin. Tujuan dari para cross-dresser ini adalah pencapaian kenikmatan erotis/ seksual/ fetish. Cross-dresser tidak hanya homo/trans, akan tetapi juga hetero. Dalam budaya Gay, cross-dresser sering disamakan dengan 'Drag'. Sedangkan Drag ( disebut juga Drag king, Drag queens, Female/ Male Impersonator) adalah seseorang yang menggunakan pakaian yang dianggap tidak sesuai dengan karakteristik gender yang seharusnya, dan seringkali "dilebih-lebihkan" dalam hal busana. Drag sering merujuk pada cara berpakaian untuk kepentingan fungsional seperti hiburan atau acara pertemuan (pesta kostum) (Anonim, 2012).

Homoseksual atau Gay adalah ketertarikan melakukan hubungan seks dengan sesama jenis (pria dengan pria atau wanita dengan wanita). Lazim disebut homoseksual atau Gay apabila dilakukan antara pria dan pria, sedangkan pada wanita disebut Lesbian. Kebalikan homoseksual adalah heteroseksual. Ekspresi homoseksual antara lain aktif bertindak sebagai pria, tidak bergantung pada seksnya, pasif bertindak sebagai wanita, serta mixed, kadang-kadang bertindak sebagai pria dan kadang-kadang sebagai wanita (Sunaryo, 2005).

\section{Metode Penelitian}

Jenis penelitian adalah kualitatif dengan pendekatan fenomenologi. Penelitian dilaksanakan pada bulan Desember 2015 sampai dengan Maret 2016. Partisipan penelitian adalah 4 orang gay anggota komunitas Semarang Gay-A Community dengan kriteria usia 20 sampai dengan 40 tahun, belum menikah dan sudah bergabung dengan komunitas lebih dari 2 tahun. Teknik sampling yang digunakan adalah purposive sampling. Teknik pengumpulan data dengan cara wawancara mendalam (In depth interview). Tahapan analisa data penelitian adalah 
memiliki gambaran yang jelas tentang fenomena yang diteliti, mencatat data yang diperoleh, membaca hasil transkrip secara berulang-ulang, menentukan arti setiap pernyataan yang penting, melakukan pengelompokkan data, mengintegrasikan hasil secara keseluruhan, klarifikasi data serta validasi data. Kredibilas data menggunakan triangulasi sumber, yaitu Ketua komunitas Semarang Gay-A Community.

\section{Hasil Dan Pembahasan}

\section{Pengetahuan tentang LGBT}

Berdasarkan hasil penelitian, didapatkan hasil bahwa, para anggota komunitas LGBT sudah mengetahui tentang LGBT, namun jawaban yang diberikan kurang lengkap. Mereka mengetahui tentang LGBT lewat informasi yang didapat dari media seperti internet, maupun dari hasil berbagi lewat komunitas Gay. Hal ini dapat dilihat dari jawaban keempat partisipan, yaitu P1, P2, P3, P4 yang menjawab bahwa LGBT adalah mereka yang sering mendapat stigma dan diskriminasi dari masyarakat. Berdasarkan hasil penelitian yang dilakukan, didapatkan hasil bahwa, menurut partisipan, perkembangan LGBT pada masa sekarang dan pada masa dulu itu berbeda. Pada masa dulu, banyak yang lebih tertutup, sedangkan pada masa sekarang, lebih terbuka karena perkembangan teknologi yang semakin canggih. Hal ini dapat dilihat pada kategori partisipan 1, 2, 3, dan 4 .

Menurut Semiawan dan Moleong (1989), LGBT ada sejak dulu. Bedanya dengan sekarang ini adalah LGBT menjadi sangat terbuka. Dulu ada, namun sulit diidentifikasi. Hal ini dibuktikan dengan penelitian kualitatif yang dilakukan oleh keduanya untuk memahami kreatifitas negatif di kalangan pelajar seperti tawuran pelajar di Jakarta. Dalam penelitian ini, peneliti mendapatkan kesempatan untuk mendalami kehidupan para Lesbian. Dan menurut peneliti, untuk mencari wanita Lesbian sangat sulit sebab sangat susah untuk melakukan komunikasi dengan komunitas tersebut. Komunitas tersebut dikatakan sangat menjaga kerahasiaan komunitas mereka, bahkan ada beberapa yang tetap menjalin hubungan dengan lawan jenis, agar terlihat normal dan tidak ketahuan oleh orang lain. Jika dibandingkan dengan sekarang, kini keadaannya sungguh bersebalikan. Komunitas LGBT malah sangat suka menonjolkan diri dan kelompoknya. Bahkan secara terbuka melakukan kampanye untuk mengajak orang lain agar bergabung dengan mereka.

2. Alasan komunitas Gay terjun ke LGBT

Berdasarkan hasil penelitian yang dilakukan, didapatkan hasil bahwa, para partisipan, mulai menyadari orientasi seksualnya pada masa SMP. Hal ini dapat dilihat 
pada kategori partisipan 1, 2, dan 3. Berdasarkan hasil wawancara dari keempat partisipan, didapatkan hasil bahwa, ketiga partisipan yaitu P1, P3, dan P4 menjawab bahwa mereka sudah menerima keadaan mereka yang sekarang. Berdasarkan hasil wawancara dengan keempat orang partisipan, yaitu P1, P2, P3, dan P4 didapatkan hasil bahwa setelah menyadari orientasi seksualnya, para partisipan lebih menjaga perilaku seksnya, yaitu dengan menjaga hubungan seksual yang aman. Berdasarkan hasil penelitian dengan 4 orang partisipan, yaitu P1, P2, P3, dan P4 didapatkan hasil bahwa partisipan belum terbuka dengan keluarganya, sehingga keluarga belum tahu orientasi seksual yang sebenarnya, sedangkan partisipan yang lainnnya sudah terbuka dengan keluarganya dan keluarganya menerimanya.

Menurut sebuah studi yang dilakukan pada tahun 2011 dari National Gay and Lesbian Task Force (NGLTF) dan National Center for Transgender Equality (NCTE) di Amerika yang berjudul “ Injustice at Every Turn.” Disana dikatakan bahwa penerimaan keluarga dapat membantu LGBT atau mereka yang terlahir dengan orientasi seksual yang berbeda dapat untuk dapat bertahan terhadap tekanan yang ditimbulkan oleh lingkungan yang tidak mendukung orientasi seksual mereka. Hal ini akan berdampak kepada kepercayaan diri para LGBT yang tentunya dapat mengurangi tingkat depresi akibat penolakan itu sendiri, penggunaan obat-obatan terlarang penyangkalan diri, dan juga mengurangi angka bunuh diri di kalangan remaja LGBT. Hal yang serupa juga dikeluarkan oleh Shannon Minter dan Jeff Krehely dalam laporannya yang berjudul "Families Matter-New Research Calls for a Revolution in Public Policy for LGBT Children and Youth" yang mengatakan bahwa dukungan positif yang diberikan oleh keluarga ternyata memberikan efek para LGBT untuk dapat menjalani hidupnya dengan lebih baik.

3. Pro dan Kontra LGBT di masyarakat

Berdasarkan hasil penelitian dengan keempat partisipan yaitu P1, P2, P3 dan P4, didapatkan hasil bahwa menurut partisipan, masyarakat yang pro, bisa menerima adanya LGBT, sedangkan masyarakat yang kontra tidak bisa menerima LGBT diakibatkan karena kurangnya informasi yang mereka dapat. Berdasarkan hasil penelitian dengan keempat partisipan, yaitu Partisipan 1, 2, 3, dan 4 didapatkan hasil bahwa keempat partisipan tersebut menyatakan bahwa mereka belum terbuka dengan masyarakat, perihal orientasi seksualnya. Berdasarkan hasil penelitian yang dilakukan pada keempat partisipan didapatkan hasil bahwa 3 orang partisipan, yaitu Partisipan 1, 2, dan 4 menjawab bahwa mereke lebih memilih cuek, terkait dengan cibiran masyarakat. Berdasarkan hasil penelitian, dengan keempat partisipan, 2 orang partisipan, yaitu partisipan 2 dan partisipan 
4 menjawab bahwa harapan mereka dari semua pro dan kontra yang ada adalah agar masyarakat lebih memahami segala pemberitaan tentang LGBT.

Menurut Dien (2008), Dosen Fakultas Teologi yang mengampu matakuliah Feminisme dan matakuliah Gender (Program Pascasarjana), LGBT masih diperdebatkan oleh masyarakat yang pro dan kontra, karena masalah "kedosaannya", yang kontra menganggap bahwa LGBT sebagai dosa dan harus dikembalikan ke jalan yang benar. Sedangkan yang pro mengatakan bahwa LGBT bukan dosa, karena mereka juga makhluk ciptaan Tuhan, dan Tuhan juga mempunyai kuasa sama besarnya untuk "mengubah" ciptaannya. Dien pun melanjutkan bahwa, LGBT tidak dapat dikatakan sebagai dosa. Sejauh bukan sebagai 'tren', karena dewasa ini banyak yang 'tiba-tiba' menjadi gay (karena) sekadar tuntutan dunia hiburan. "Kelainan" seksual ini dapat terjadi karena berbagai faktor, seperti yang dijelaskan oleh Freud dalam penelitiannya (Dawam, 2005). Yaitu Faktor Prinsip hidup, dimana menurut Freud, setiap manusia memiilki dua prinsip, yaitu mati dan hidup (dead and life). Faktor Lingkungan, berkenaan dengan hal ini, Freud memegang prinsip determinisme psikologis, yaitu setiap manusia telah menentukan sebelumnya untuk hidup di sebuah lingkungan tertentu. Faktor Kebebasan Seksual (Free Sex), kebebasan sex (free sex) pada titik tertentu akan mendorong seseorang untuk mencari kepuasan seks dari gaya dan varian seks lainnya, atau terlibat dalam aktivitas seksual seperti yang dilakukan oleh komunitas LGBT. Faktor Genetik, perkembangan biologi molekuler dan genetika memberi warna baru dalam memahami eksternal manusia. Faktor Hormon, dalam ilmu biologi disebutkan bahwa sifat maskulin dan feminin sangat ditentukan oleh hormon testosteron dan progesteron. Faktor ketidakpuasan seks dengan pasangan, ketidakharmonisan hubungan seksual suami istri menjadi salah satu faktor berupa seseorang mengalihkan orientasi seksualnya seperti aktivitas seksual yang dilakukan oleh kaum LGBT.

4. Dunia pekerjaan yang dimasuki oleh komunitas Gay

Berdasarkan hasil penelitian dengan keempat partisipan, yaitu partisipan 1, 2, 3, dan 4 didapatkan hasil bahwa para partisipan sudah memberitahukan jati diri mereka di tempat kerja, termasuk kepada pimpinan dan teman kerja. Berdasarkan hasil penelitian pada keempat partisipan, yaitu partisipan 1, 2, 3, dan 4 didapatkan hasil bahwa, para partisipan mengatakan bahwa, mereka belum pernah mengalami diskriminasi di tempat kerja, sedangkan untuk perlakuan di tempat kerja juga, keempat partisipan mengatakan tidak ada masalah dengan perlakuan para rekan kerja mereka di tempat kerjanya. 
Menjadi pekerja yang memiliki orientasi Lesbian, Gay, Biseksual, dan Transgender (LGBT) berarti berada di persimpangan antara menjadi diri sendiri atau menjadi bagian dari arus utama, yakni heteroseksual. Ketika seorang LGBT berpendidikan tinggi, mereka mempunyai ruang lebih besar untuk menjadi diri sendiri dan menemukan tempat kerja yang sesuai dengan orientasi dan pemikiran mereka. Hal itu disebabkan oleh berkualitasnya kemampuan dan keterampilan mereka sehinga mencari pekerjaan sesuai tidak pernah menjadi masalah. Hal yang berbeda menimpa pekerja LGBT dari kalangan pendidikan rendah dimana mereka memiliki ruang sempit untuk mengekspresikan diri, dimana urusan mendapat pekerjaan yang bisa mendukung orientasi mereka sulit dicapai. Alhasil, merahasiakan jati diri menjadi satu-satunya pilihan agar bisa mencari nafkah. Fakta tersebut dirangkum dalam sebuah penelitian berjudul 'Identitas Gender dan Orientasi Seksual: Mempromosikan Hak Asasi, Diversitas dan Persaman di Dalam Dunia Kerja' yang dilakukan oleh Organisasi Buruh Internasional (ILO) yang bekerjasama dengan Pusat Studi Kependudukan dan Kebijakan (PSKK) Universitas Gadjah Mada (UGM) Yogyakarta (Linggasari, 2015). Penelitian kualitatif yang bertujuan untuk mengetahui pengalaman kaum LGBT di dunia kerja ini, mengambil partisipan dengan latar belakang pekerjaan yang bervariasi. Ada yang bekerja di salon, restoran, cafe, toko swalayan, bank, kantor swasta, lembaga swadaya masyarakat, dan juga pegawai negeri sipil. Menurut hasil wawancara penelitian tersebut, kebanyakan dari mereka beranggapan bahwa mereka cukup toleran terhadap LGBT, tetapi pada tataran perilaku, mereka keberatan mempunyai teman sekerja atau atasan LGBT. Sedangkan, terkait pertanyaan ‘sudah adakah kesadaran dari pihak perusahaan mengenai kehadiran mereka?' pihak perusahaan yang diwawancara mengatakan bahwa mereka sudah mengetahui bahwa LGBT itu ada di perusahaan. Akan tetapi mereka memandang LGBT sebagai kelompok yang melenceng dari norma-norma sosial yang ada. Pendekatan yang sering dipakai oleh perusahaan atau organisasi buruh adalah kegiatan "siraman rohani", dengan harapan para pekerja LGBT ini akan kembali ke "jalan yang normal” (Linggasari, 2015).

5. Dampak orientasi seksual terhadap kesehatan

Berdasarkan hasil penelitian pada keempat partisipan, yaitu partisipan 1,2,3, dan 4 didapatkan hasil bahwa partisipan tidak setuju dengan pernyataan bahwa perilaku seks bebas diidentikkan dengan komunitas mereka, sebab hal itu juga dilakukan oleh kaum heteroseksual. Berdasarkan hasil penelitian dengan keempat orang partisipan, yaitu partisipan 1, 2, 3, dan 4, didapatkan hasil bahwa, menurut partisipan, pemeriksaan kesehatan itu sangat penting untk menjaga diri, terutama bagi mereka yang memiliki faktor 
resiko tinggi. Berdasarkan hasil penelitian terhadap keempat partisipan, 3 orang partisipan, yaitu partisipan 1, 3, dan 4 menjawab bahwa pelayanan kesehatan yang diberikan pada komunitas mereka selama ini baik-baik saja dan tidak ada masalah. Berdasarkan hasil penelitian terhadap keempat orang partisipan, yaitu partisipan 1, 2, 3, dan 4, didapatkan hasil bahwa, artisipan tidak setuju dengan pernyataan tersebut, karena menurut mereka, justru yang menjadi penyumbang terbesar adalah dari kaum heteroseksual.

HIV yang merupakan singkatan dari Human Immunodeficiency Virus adalah virus penyebab AIDS. Virus ini menyerang dan merusak sistem kekebalan tubuh sehingga kita tidak bisa bertahan terhadap penyakit-penyakit yang menyerang tubuh kita. Sistem kekebalan tubuh rusak atau lemah mudah terserang penyakit yang ada di sekitar kita seperti TBC, Diare, Sakit Kulit, dll. HIV terdapat di dalam cairan tubuh seseorang yang telah terinfeksi seperti di dalam darah, Air Mani (cairan sperma) atau cairan vagina atau Air Susu Ibu. Sebelum HIV berubah menjadi AIDS, penderitanya akan tampak sehat dalam kurun waktu kira-kira 5 sampai 10 tahun. Walaupun tampak sehat, mereka dapat menularkan HIV pada orang lain melalui hubungan seks yang tidak aman, transfusi darah atau pemakaian jarum suntik secara bergantian.

\section{Kesimpulan}

Partisipan mengetahui tentang pengertian LGBT namun kurang lengkap. Parsitipan terjun ke LGBT secara alami, dimana partisipan mulai menyadari orientasi seksualnya ketika masa puber, yaitu pada masa SMP. Parsitipan beranggapan masyarakat yang kontra lebih banyak dibandingkan yang, hal ini disebabkan karena banyaknya pemberitaan-pemberitaan yang negatif tentang LGBT di media, serta kurangnya informasi tentang LGBT yang diperoleh masyarakat. Partisipan sudah memberitahu perihal jati diri mereka di tempat kerja yaitu kepada pimpinan dan rekan kerja, soal diskriminasi di tempat kerja, partisipan mengatakan bahwa selama ini mereka belum pernah mengalami diskriminasi di tempat kerjanya. Partisipan berpendapat bahwa orientasi seksual mereka juga berpengaruh terhadap kesehatan mereka, namun partisipan tidak setuju bila seks bebas diidentikan dengan komunitas mereka dan komunitas mereka yang dikatakan menjadi salah satu penyumbang terbesar HIV/ AIDS, karena perilaku seks bebas juga dilakukan oleh kaum heteroseksual dan penyumbang HIV/ AIDS terbesar justru berasal dari kaum heteroseksual.

Komunitas gay diharapkan agar lebih memahami tentang LGBT, lebih mengembangkan diri di masyarakat umum, harus lebih memahami lagi tentang arti pentingnya pemeriksaan 
kesehatan, serta memberikan informasi yang jelas tentang pemeriksaan kesehatan, bagi teman sekomunitas yang belum menyadari tentang arti pentingnya pemeriksaan kesehatan. Masyarakat diharapkan agar masyarakat lebih memahami lagi tentang LGBT dengan menambah pengetahuan dan informasi dari sumber yang jelas, sehingga pandangan-pandangan yang negatif soal LGBT disertai dengan stigma dan diskriminasi di masyarakat umum terhadap LGBT tidak akan terjadi lagi.

\section{Daftar Referensi}

Adnamazida, Rizqi. 2012. Hubungan Pria Sesama Jenis Ternyata Rentan Masalah Kesehatan. www.merdeka.com. Diakses tanggal 9 Maret 2016

Anonim. 2012. Mengenal Orientasi Seksual. www.mitrawacana.or.id Diakses pada tanggal 9 Maret 2016

- 2015. Faktor- Faktor Penyebab Terjadinya LGBT. www.perpusmuslim.com. Diakses Desember 2015

www.voaindonesia.com. Diakses pada tanggal 3 Januari 2016

Tanpa Tahun. Perjalanan Sejarah Waria, Gay, dan Lesbian. www.gayanusantara.or.id. Diakses pada tanggal 3 Januari 2016

2014. LGBT Dalam Perjalanan Sejarah. www.islampos.com. Diakses pada tanggal 3 Januari 2016

- Tanpa Tahun. Perilaku Seks Bebas. www.digilib.unimus.ac.id. Diakses pada tanggal 10 Agustus 2016

Daryono, Aziz. 2013. Transgender, Transeksual, dan Waria. www.suarakita.org. Diakses pada tanggal 3 Januari 2016

Linggasari, Yohanie. 2015. Survei UGM: Pemerintah Belum Lindungi Pekerja $\quad$ LGBT.

m.cnnindonesia.com. Diakses pada tanggal 10 Agustus 2016

Lintangella, Rr. 2015. Semarang Gay-A Community (SGC): Wadah Nyata Penanggulangan HIV/ AIDS Pada Komunitas Resiko Tinggi. Semarang IYHPS-News Letter. Tersedia di www.iyhps.org

Okdinata. 2009. Religiusitas Kaum Homoseks. Yogyakarta : Universitas Islam Negeri Sunan Kalijaga

Rahman, A.S. 2015. Jumlah Populasi Gay di Indonesia dan Dunia. www.sixpackmagazine.net. Diakses pada tanggal 3 Januari 2016 
Reksodirdjo, W. 2011. Homoseksualitas di Indonesia: Antara Kenyataan Dan Tersedia di https://icssis.files.wordpress.com/2012/05/1819072011_32.pdf

Yuliyanto, Iwan. 2013. Runtuhnya Teori Gen Gay. www.iwanyuliyanto.com. Diakses

Desember 2015 